\title{
Becoming a mompreneur: Parental leave policies and mothers' propensity for self-employment
}

Citation for published version (APA):

Gerards, R., \& Theunissen, P. (2018). Becoming a mompreneur: Parental leave policies and mothers' propensity for self-employment. Maastricht University, Graduate School of Business and Economics. GSBE Research Memoranda No. 025 https://doi.org/10.26481/umagsb.2018025

Document status and date:

Published: 04/12/2018

DOI:

10.26481/umagsb.2018025

Document Version:

Publisher's PDF, also known as Version of record

\section{Please check the document version of this publication:}

- A submitted manuscript is the version of the article upon submission and before peer-review. There can be important differences between the submitted version and the official published version of record.

People interested in the research are advised to contact the author for the final version of the publication, or visit the DOI to the publisher's website.

- The final author version and the galley proof are versions of the publication after peer review.

- The final published version features the final layout of the paper including the volume, issue and page numbers.

Link to publication

\footnotetext{
General rights rights.

- You may freely distribute the URL identifying the publication in the public portal. please follow below link for the End User Agreement:

www.umlib.nl/taverne-license

Take down policy

If you believe that this document breaches copyright please contact us at:

repository@maastrichtuniversity.nl

providing details and we will investigate your claim.
}

Copyright and moral rights for the publications made accessible in the public portal are retained by the authors and/or other copyright owners and it is a condition of accessing publications that users recognise and abide by the legal requirements associated with these

- Users may download and print one copy of any publication from the public portal for the purpose of private study or research.

- You may not further distribute the material or use it for any profit-making activity or commercial gain

If the publication is distributed under the terms of Article $25 \mathrm{fa}$ of the Dutch Copyright Act, indicated by the "Taverne" license above, 
Ruud Gerards,

Pomme Theunissen

Becoming a mompreneur: Parental leave policies and mothers' propensity for selfemployment

RM/18/025

\section{GSBE}

Maastricht University School of Business and Economics

Graduate School of Business and Economics

P.O Box 616

NL- 6200 MD Maastricht

The Netherlands 


\title{
Becoming a Mompreneur: Parental leave policies and mothers' propensity for self- employment
}

RUUD GERARDS ${ }^{\mathrm{a}}$ and POMME THEUNISSEN ${ }^{\mathrm{b}}$

${ }^{a}$ Research Centre for Education and the Labour Market (ROA), School of Business and Economics, Maastricht University, P.O. Box 616, NL-6200 MD Maastricht, The Netherlands (e-mail:R.Gerards@maastrichtuniversity.nl).Corresponding author

${ }^{b}$ Maastricht University, Department of Finance, School of Business and Economics, Maastricht University, P.O. Box 616, NL-6200 MD Maastricht, The Netherlands (e-mail: p.theunissen@maastrichtuniversity.nl).

\section{HIGHLIGHTS:}

- A decrease in the level of generosity of parental leave policies decreases mothers' propensity to become "mompreneur".

- A reduced time-period of paid parental leave decreases the probability to become "mompreneur".

\begin{abstract}
:
Contractionary parental leave policy reforms decrease the time mothers can stay at home after giving birth. This might discourage them to become an entrepreneur. Exploiting a German parental leave policy reform, we apply a regression discontinuity approach to establish a causal relationship between parental leave policies and the probability for mothers to become entrepreneurs (i.e., "mompreneurs"). We find that a decrease in the generosity of parental leave lowers the odds of mothers to become self-employed by $17 \%$. We show additional evidence that suggests that this is particularly due to the reduced period of paid parental leave.
\end{abstract}

\section{ARTICLE INFO:}

JEL classification: H31, J10, J20, L26

Keywords: Female entrepreneurship, Mompreneurs, Parental leave, Policy reform, Female labor supply

\footnotetext{
* We thank Jaap W.B. Bos, Martin Carree, Alexander Grigoriev, Andries de Grip, Olivier Marie, Ken Mayhew and Sanne van Wetten for their helpful comments and insights. We also thank participants at the Belgian Entrepreneurship Research Day (2018), the European Academy of Management Conference (EURAM 2018), the European Association of Labour Economists Conference (EALE 2018) and the Finance PhD Colloquium (School of Business and Economics, Maastricht University).
} 


\section{Introduction}

Women currently represent $34 \%$ of the European self-employed workforce (European Commission, 2017). The European Commission considers female entrepreneurial potential to be an "under-exploited source of economic growth and jobs that should be further developed" (European Commission, 2017), and female entrepreneurship has been at the center of various public policies that seek to make this career path more attractive (de Jong, 2013). However, public policy initiatives in areas not directly targeted to promoting female entrepreneurship, such as policies regarding generosity of parental leave, might also affect women's choice to become self-employed, because parental leave affects the ability to reconcile business and family concerns. Reconciling these two roles is recognized as one of the five main challenges for female entrepreneurs (European Commission, 2017). Gottlieb et al. (2016) find that increasing job-protected parental leave time by several months increases entrepreneurship among mothers in Canada. A reduction in generosity of parental leave may therefore result in reduced incentives for mothers to become self-employed, as the time they spend not in the labor market is shorter, implying less "paid time off" to think about their careers and incubate potential business ideas.

We investigate the effect of a reform in parental leave policy on the propensity of mothers to switch to self-employment within the first six years after childbirth. We label women who do so as "mompreneurs" (Richomme-Huet et al., 2013).

We build on a contractionary parental leave reform in Germany, implemented on January 1, 2001, that was the first to break a decades-long trend in which successive changes in parental leave policies were ever more generous in nature, leading to consistent increases in child-related work interruptions by German mothers. The 2001 parental leave reform, however, incentivized mothers to return to their jobs sooner (Ziefle and Gangl, 2014). We estimate the effect of this reform on the propensity to become a mompreneur by a regression discontinuity design (RDD) using longitudinal data from the German Socio-Economic Panel 
(GSOEP). Our contribution is twofold. First, we add to the literature by formally defining and identifying mompreneurs among the universe of female entrepreneurs. Second, we add to the scant literature that studies the effects of parental leave policy reforms on female entrepreneurship pioneered by Gottlieb et al. (2016), who examine the effect of an increase in the length of job-protected leave on mother's self-employment in Canada. We add to this study by estimating the effect of a decrease in parental leave generosity, in terms of both the duration of cash benefit payments and the level of these cash benefits, on mothers' propensity to become mompreneurs. We also elucidate whether the effects of increases in parental leave generosity on mother's self-employment, as studied by Gottlieb et al. (2016), are symmetrical to the effects of decreases in parental leave generosity that we study. Moreover, parental leave policies and related labor force participation decisions are shaped by cultural context (Budig et al., 2012), social norms, and mothers' preferences regarding economic dependence (Bergemann and Riphahn, 2015). This leads to strong cross-country differences in mothers' labor market prospects and concomitant behavior (Gangl and Ziefle, 2009; Cascio et al., 2015). Thus, we also add to the literature on parental leave policy and female selfemployment by investigating Germany, a country with historically generous parental and family policies along with traditional family roles (Ondrich et al., 1996; Gottschall and Bird, 2003).

The remainder of this paper proceeds as follows. Sections 2.1 through 2.3 discuss respectively the context of female entrepreneurship in general, the thin literature on mompreneurship, and how parental leave policies impact young mother's labor force participation. In Section 3 we describe the policy reform of interest. Section 4 presents our data and our definition of mompreneurs, followed by Section 5 which details our identification strategy. Finally, Sections 6 and 7 present our results and robustness checks, and our conclusions. 


\section{Female entrepreneurs, mompreneurs and parental leave policies}

\subsection{Reconciling work and family as a driver for female entrepreneurship}

Women's motivations to become self-employed differ from their male counterparts, impacting the ensuing performance of their firms (Fairlie and Robb, 2009). Moreover, women-led enterprises are on average smaller in size, less likely to grow, and disproportionately present in the retail and services sectors (Orser et al., 2006). These sectors feature relatively low barriers to entry, high competition, and low profit margins, leading to lower potential returns (Verheul and Thurik, 2001) and lower sales growth (Riding and Swift, 1990). In terms of conventional performance measures, women seem to underperform compared to their male entrepreneur counterparts (du Rietz and Henrekson, 2000). Women are also far less inclined to be involved in entrepreneurial activities than men in any country studied (Jennings and Brush, 2013).

In explaining these differences between male- and female-led companies, Korsgaard (2007) argues that they stem from differing contexts, in which factors other than profit might matter more in female-led firms compared to male-led firms. Hence, the motivations for women to start a business might be less based on longing for financial success, and more on factors such as how meaningful their businesses can be for society (Nel et al., 2010). Similarly, Jean and Forbes (2012) argue that intrinsic motivation is a major reason for firm creation by mothers. ${ }^{1}$ Moreover, Kirkwood (2009) finds that family considerations regarding children and the family's practical and emotional needs, motivate women into entrepreneurship significantly more often than men. These family considerations likely contribute to the finding of Carter and Cannon (1992) that female entrepreneurs tend to run their businesses in ways that prevent conflict between their personal and professional interests.

\footnotetext{
${ }^{1}$ The authors define as "intrinsic" motivation the desire to put skills to use, the desire to have something for themselves or their children, and the desire to help people (Jean and Forbes, 2012, p.123).
} 
Another family-related way in which men and women differ in their motivation to become entrepreneurs is that women suffer a motherhood penalty on wages. Gangl and Ziefle (2009) assess these wage penalties for women and state that "motherhood increases the likelihood of working part-time, and implies mobility into lower-prestige and typically female occupations as well as entry into self-employment" (Gangl and Ziefle, 2009, p. 350). However, these authors do not further elaborate on this path into entrepreneurship.

\subsection{Mompreneurs}

Richomme-Huet et al. (2013) discuss and compare several definitions of mompreneurs currently found in the literature; they are mostly qualitative in nature. These mompreneur definitions are: "women entrepreneurs who are also mothers" (Jean and Forbes, 2012, p. 112); "a female business owner actively balancing the role of mom and entrepreneur" (Korsgaard, 2007, p. 43); "one particular subset of women entrepreneurs: those who set up a business in order to enable them to both work and care for young children" (Duberley and Carrigan, 2012, p. 629); "women who articulated the desire to be selfemployed to enable them to combine work and motherhood" (Duberley and Carrigan, 2012, p. 634); and "an individual who discovers and exploits new business opportunities within a social and geographical context that seeks to integrate the demands of motherhood and business-ownership" (Ekinsmyth, 2011, p. 104). All these definitions have in common that being one's own boss gives these women the flexibility to manage their households and families as they desire, while earning their own income (Carr, 1996).

In line with the motivations of female entrepreneurs described in Section 2.1, profit and wealth creation are not the primary purpose for mompreneurs to start their businesses. The approach, rather, is to kill two birds with one stone: earning money and looking after their families. As mentioned by Nel et al. (2010), the most outstanding fact is that "it is not 
all about wealth creation" (p. 12). Even more so, mompreneurs are actually reluctant to grow their businesses (Ekinsmyth, 2011; Duberley and Carrigan, 2012). The latter authors find that all of the mompreneurs interviewed “... agreed that they would not want their business to expand to the extent where it challenged their ability to be available to their children" (Duberley and Carrigan, 2012, p. 638), hence also limiting their profit potential.

Several common characteristics of mompreneur-businesses are known. Among others, most mompreneur-businesses are reported to be home based (Ekinsmyth, 2011; Duberley and Carrigan, 2012) and rely heavily on Internet sales (Ekinsmyth, 2011 and 2013; Ozurumba, 2012). This enables mompreneurs to maintain flexible work schedules tailored around their kids, including getting up very early in the morning or working late at night, when the kids are sleeping, to attend to the business (Duberley and Carrigan, 2012). Strong bonds among mompreneurs is another notable characteristic relative to male entrepreneurs; mompreneurs rely heavily on associations to establish business relations (Nel et al., 2010; Richomme-Huet and Vial, 2014). The personal profiles of mompreneurs are also very similar: middle class (Ozurumba, 2012), middle aged, and of course being mothers of young children, with the business started after they became mothers (Jean and Forbes, 2012; Ekinsmyth, 2013).

\subsection{How motherhood and parental leave policies affect mothers' labor force participation}

To our knowledge, Gottlieb et al. (2016) is the only study that relates changes in parental leave policies to changes in mother's propensity to become entrepreneurs. These authors analyze the effect of extension of Canadian job-protected leave entitlements after maternity, from 7 to 12 months, implemented in 2000. They find that this more generous parental leave policy led to a 1.8 percentage point increase in entrepreneurship among mothers five years later. They also find that mothers with more human and financial capital 
respond more strongly to the reform. They raise the suggestion that mothers tend to use this increase in paid time off to incubate their businesses (Gottlieb et al., 2016).

Although there are no studies on the effect of parental leave policies on female entrepreneurship for Germany, the broader literature on parental leave policies and female labor supply (see Kalb (2017) for a recent overview) contains various studies that measure the impact of changes in Germany's parental leave policies on maternal labor force participation in general. These studies consistently find that expansionary changes in entitlement duration significantly increased the length of leave taken by mothers and delayed their re-entry into the labor force after childbirth, whereas the contractionary policy reforms of the 2000s induced German mothers to return to work sooner ${ }^{2}$ (Ondrich et al., 1996; Dustmann and Schönberg, 2012; Schönberg and Ludsteck, 2014; Ziefle and Gangl, 2014; Kalb, 2017). These findings suggest that the opportunity costs of employment interruption have decreased, because expansions in parental leave entitlement have weakened the requirement for a continuous work history and compensated lost income with financial benefits. Gangl and Ziefle (2015) underscore this, using difference-in-difference estimations to show that mothers' subjective work commitment decreased with the various expansionary policy changes that occurred between 1979 and 1992, while displaying an increased preference to care for their families. Similar relations between the generosity of parental leave policies and mothers' decreased work commitment are also found in other countries, for example, in Canada, following an extension of job-protected maternity leave (Baker and Milligan, 2008); in Norway, following a series of expansionary parental leave reforms (Rønsen and Sundström, 2002; Dahl et al., 2016); and in the Czech Republic, following an extension of parental leave benefits (Mullerova, 2017).

\footnotetext{
${ }^{2}$ Merz (2005) finds that the less generous 2001 reform induced some married women with young children to work part-time. Moreover, the fraction of young mothers that was working part-time between twenty and thirty hours per week decreased, whereas the fractions of mothers working between one and ten, and between ten and twenty hours per week both increased.
} 
Following the logic of Gottlieb et al. (2016)—who suggest that a positive relation between parental leave policy generosity and paid time off for mothers enables them to think about their careers and incubate their business ideas-we hypothesize that a reform in the opposite direction (decreasing the parental leave policy's level of generosity) lowers mothers' propensity to become mompreneurs, because women have less paid time off to think about their careers and incubate their business ideas.

\section{The 2001 policy reform in Germany}

Before January 1, 2001, all mothers had 14 weeks of mandatory maternity leave (Mutterschutzgesetz), and each parent couple was entitled to 34 months of job-protected postbirth parental leave. ${ }^{3}$ This 34-month period of leave included a 22-month period of child rearing benefits (Erziehungsgeld). For the first 6 of these 22 months, the payment equaled $€ 300$, was tax-exempt, and not linked to the previous labor market status of the parent. From the seventh month onwards, the amount depended on the average salary received during the three months preceding maternity leave (OECD, 2017b). In sum, out of 34 months of parental leave, 22 included a benefit receipt in the form of child rearing benefits, whereas the remaining 12 months were "unpaid," albeit still job-protected, guaranteeing the possibility to return to their employer(s). The parental leave period could be used up to the child's third birthday (Thévenon and Solaz, 2013; OECD, 2017b).

The reform of January 1, 2001 introduced flexibility into the child rearing benefit payments. Parents could choose either a period of 22 months receiving $€ 300$ monthly for the full period, or a period of 10 months receiving $€ 450$ monthly. ${ }^{4}$ These monthly payments were income dependent and parents with an annual income above $€ 37,500$ were excluded from

\footnotetext{
${ }^{3}$ Although both parents could claim the leave, in practice this was almost exclusively taken by mothers (Gangl and Ziefle, 2015).

${ }^{4}$ Regardless of the chosen payment option, the earlier 34 months of job protected leave and the 14 weeks of maternity leave were retained (Merz, 2005; OECD, 2017b).
} 
receiving any of these benefits during parental leave. ${ }^{5}$ According to the OECD, this rendered paid parental leave inherently less generous than before in terms of the number of paid leave weeks, as shown in Figure 1 (Thévenon and Solaz, 2013; OECD, 2017a). The 10- or 22month (depending on parents' choice) paid leave period could be used up to the child's second birthday; the third year of unpaid parental leave could be used until the child's eighth birthday. See table A.1 of the appendix for a concise summary of the policy change.

\section{Figure 1}

\section{Weeks of paid leave in Germany 1970-2008}

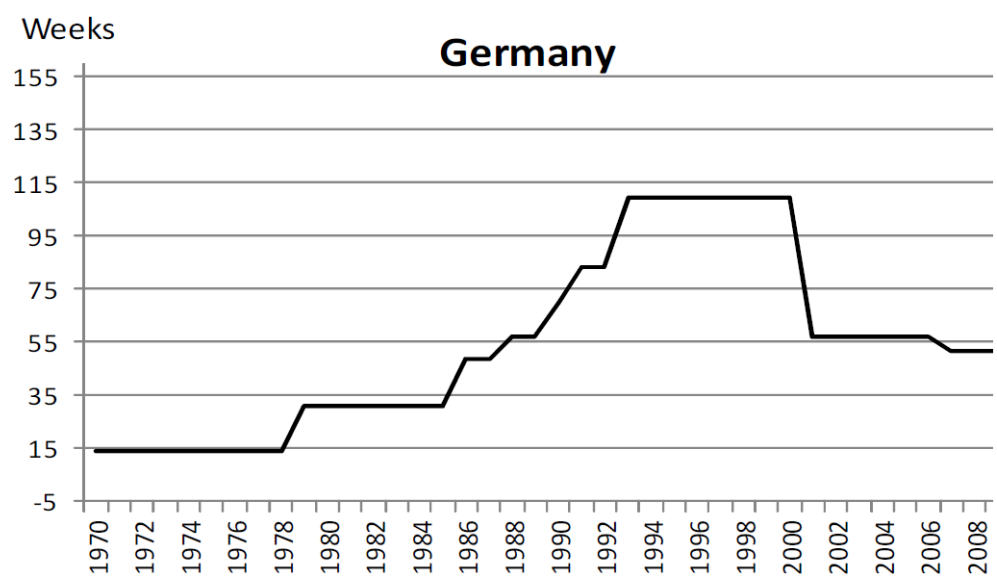

Notes.- Weeks of paid leave as represented by the OECD. The OECD expresses leave duration in weeks by using $X *(52 / 12)$ to translate months to weeks. The weeks represented in the graph include the 14 weeks of mandatory maternity leave.

Source.- Reprinted from "Labour market effects of parental leave policies in OECD countries," by O. Thévenon and A. Solaz, 2013, OECD Social, Employment and Migration Working Papers, No. 141, OECD Publishing, p 42 (Figure A1.1).

\section{Data set}

We use data from GSOEP for the years 1996 to 2011. This longitudinal study began in 1984 and conducts approximately 30,000 annual interviews in the German adult population, spanning roughly 11,000 households. It includes a wide array of variables, such as demographics and household composition, employment, health and satisfaction measures and occupational biographies (Haisken-DeNew and Hahn, 2010; Goebel et al., 2018). The

\footnotetext{
${ }^{5}$ See Thévenon and Solaz (2013) for all details concerning the payment schedule.
} 
sample we use contains all 5,740 mothers who gave birth in the years 1996-2005, surrounding the 2001 policy reform. This time frame is based on Gangl and Ziefle (2009), who investigate behavioral changes in labor market participation after motherhood for a fiveyear time frame after giving birth, and Gathmann and Sass (forthcoming), who also use a five-year time frame in their analysis of mothers' labor market responses to child care-related policy changes. ${ }^{6}$ In our sample of 5,740 mothers, we observe a total of 8,342 births; ${ }^{7} 4,479$ before January 1, 2001 and 3,863 after. ${ }^{8}$ Figure 2 shows the trends in childbirths over the different survey waves before and after the 2001 reform. The figure depicts a decrease in the childbirth rate for the first and second child.

\section{Figure 2}

\section{Childbirth incidence in our sample of mothers}

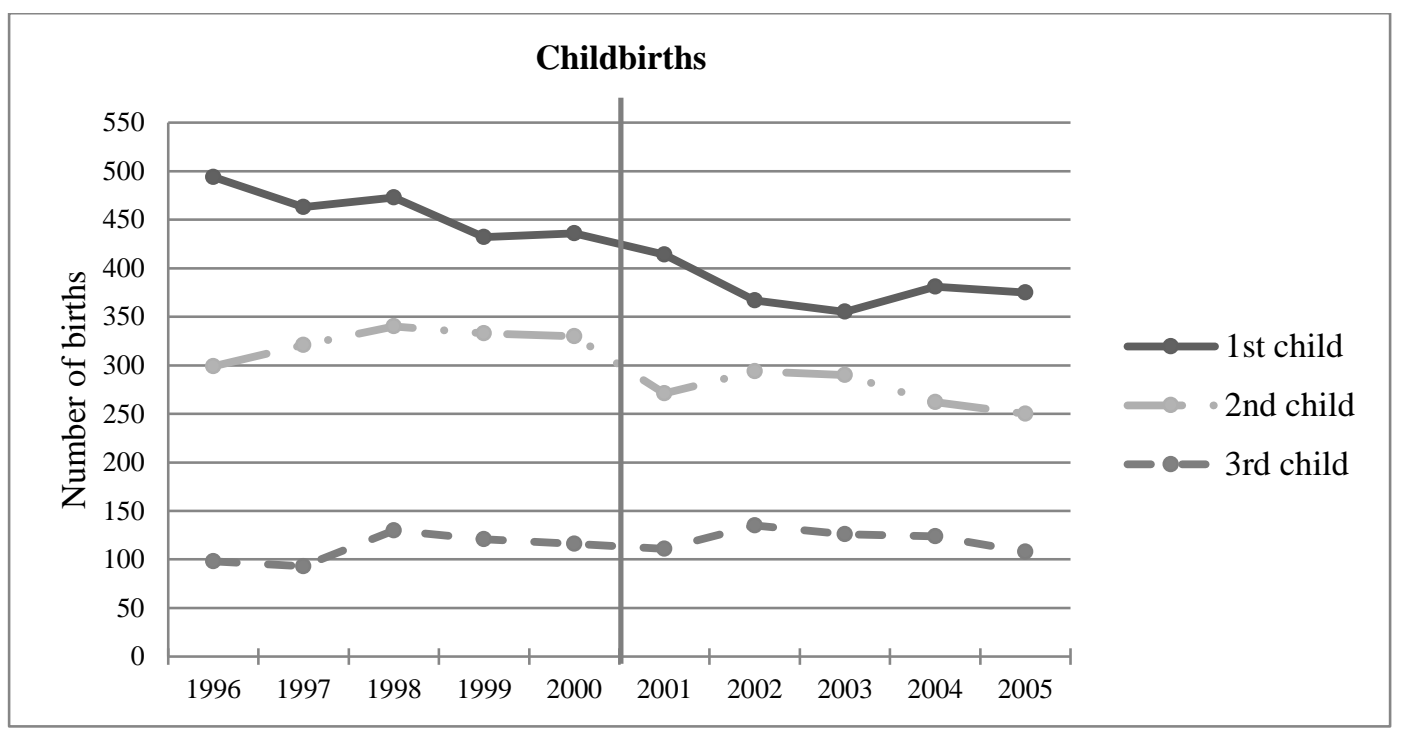

Notes.- Number of childbirths including the first, second and third born child of mothers in our sample. Each birth entitles the mother to renewed parental leave benefits. The sample contains 5,740 mothers and 8,432 births.

\footnotetext{
${ }^{6}$ Further, Kluve and Schmitz (2017) and Raute (2017) also use a five-year time frame to analyze effects of parental leave policy reforms on women's employment and fertility, respectively.

${ }^{7}$ We retrieved childbirth information from GSOEP's 'Biobirth' dataset.

${ }^{8}$ Each birth entitles a mother to (renewed) parental leave rights.
} 


\subsection{Defining mompreneurs}

We define mompreneurs as "women who move into self-employment surrounding childbirth," wherein the term "surrounding childbirth" spans from pregnancy (t-1) until six years after childbirth $\left(t_{+6}\right)$, for the first, second, or third child. Our definition follows Ziefle and Gangl (2014), who also use a cut-off criterion at six years (when children normally enter primary school) in their study on the duration of mothers' employment interruptions in Germany. The information needed to construct our mompreneur variable stems from the GSOEP personal questionnaire. In each of the waves, respondents are asked retrospectively whether they changed their professional occupation in the past year. The subsequent question asks what type of occupational change this was: "becoming self-employed" is one of the possible answers. We use the GSOEP waves of 1996 to 2011, as this time period includes, for each mother who gave birth in the years 1996 to 2005, the six years' time to become a mompreneur. The data contain 181 mompreneurs according to our definition. ${ }^{9}$

\subsection{Descriptive statistics of our sample}

Table 1 summarizes the means and standard deviations for several personal, household, and labor market characteristics of our sample, which consists of all women who gave birth between 1996 and 2005. We present separate statistics for those mothers who according to our definition are mompreneurs, and all other mothers. The table shows that there is no significant difference among the sample of all other mothers and the mompreneurs regarding the age at which they become mothers, their marital status, personal income, home ownership, origin (East or West Germany) ${ }^{10}$ and weekly hours of work.

\footnotetext{
${ }^{9}$ In our sample of 181 mompreneurs, 109 mothers became self-employed within three years after childbirth. This time span of three years after childbirth corresponds roughly to the combination of 34 months of allocated parental leave and the 14 weeks of maternity leave. 98 mothers became mompreneurs within the first six years after birth of their first child, 66 mothers within six years after birth of their second child, and 17 within six years after birth of their third child.

${ }^{10}$ East and West Germany are considered to be distinct in terms of their view on families and women's role therein. We can disregard this here, as the sample is not statistically diverse among the regions (Budig et al., 2012; Camp et al., 2016; Ziefl and Gangl, 2014).
} 
However, compared to the sample of all other mothers, the mompreneurs are more highly educated and have higher monthly household income. Additionally, several childcentered characteristics stand out: on average, the mompreneurs have more children, spend more time with them, and have a far greater tendency to work from home than the sample of all other mothers.

\section{Table 1}

\section{Descriptive statistics}

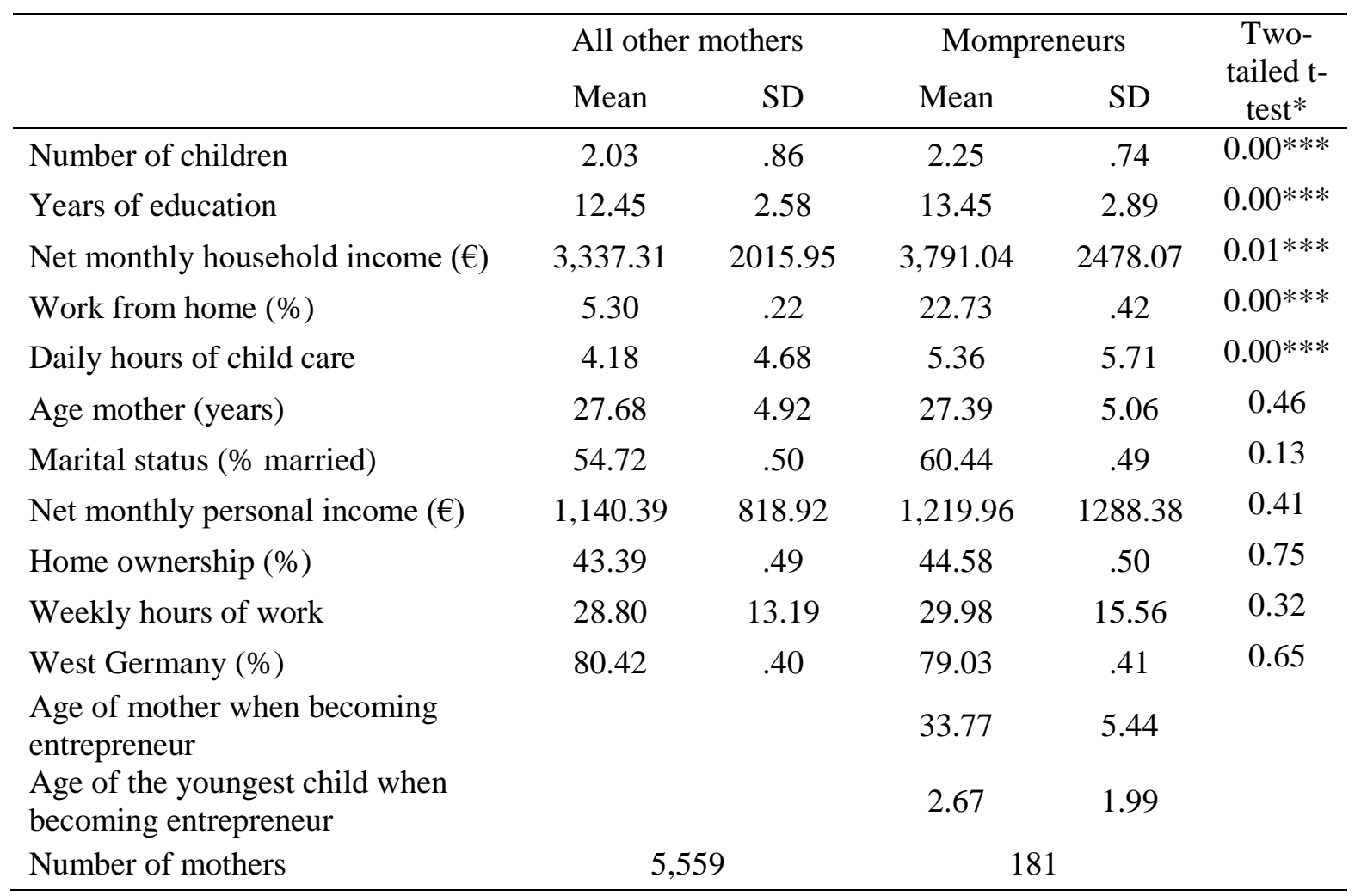

Notes.- Table 1 reports descriptive statistics for the 5,559 mothers in our sample who are not mompreneurs, and the 181 mothers who are mompreneurs. The table reports p-values of two tailed t-tests for differences in means between the two groups. Significance levels: $* \mathrm{p}<0.10, * * \mathrm{p}<0.05, * * * \mathrm{p}<0.01$.

The type of businesses that mompreneurs operate can be derived from the question on the type of entrepreneurial activity in which the respondent is involved. Of our 181 mompreneurs, $35 \%$ indicate being a freelancer; $47 \%$ work without co-workers; $13 \%$ have less than 9 co-workers; $2 \%$ have more than 9 co-workers; and 3\% help in the family 
business. These business types are in line with the findings of Duberley and Carrigan (2012) and Ekinsmyth (2011).

\section{Identification strategy}

We use a regression discontinuity approach to identify the causal effect of a change in parental leave generosity on the probability of mothers becoming mompreneurs. We estimate the difference in the probability of becoming mompreneur between mothers who gave birth before the policy change and mothers who gave birth after the policy change. A key assumption of this natural experiment is that the discontinuous change in the probability to become a mompreneur is due to this policy change only.

Two conditions need to be fulfilled for a woman to become a mompreneur: she needs to be a mother, and she needs to become self-employed between pregnancy $\left(\mathrm{t}_{-1}\right)$ and six years after childbirth $\left(t_{+6}\right)$. Together, these conditions help define a mompreneur. We start by defining $E_{i t}$ the variable that denotes entrepreneurship, where $E_{i t}=1$ when the woman is selfemployed, and $E_{i t}=0$ otherwise. Obtaining parental leave is conditional on having given birth. Following standard regression discontinuity terminology, our assignment variable is therefore childbirth. ${ }^{11} x_{\mathrm{it}}$ is the variable that captures the year in which a mother gives birth, where $x_{\mathrm{it}}=1$ in the year she gives birth, and $x_{\mathrm{it}}=0$ if there is no birth in this year. All women in our data set have given birth at least once during the sample period. But not all become mompreneurs. After all, becoming a mompreneur, denoted by $M_{i t}$, is the product of $E_{i t}$ and $x_{i t}$ :

$$
V_{i t}=E_{i t} \times \sum_{\mathrm{t}=-1}^{6} x_{i t}
$$

Therefore

$$
M_{i t}\left\{\begin{array}{l}
=1 \text { if } V_{i t}>0 \\
=0 \text { if } V_{i t}=0
\end{array}\right.
$$

\footnotetext{
${ }^{11}$ The assignment variable is also referred to as the "forcing" or "running" variable in the literature. See Lee and Lemieux (2010) for further explanations on regression discontinuity.
} 
Consistent with our definition of a mompreneur, the year in which a mother gives birth, $x_{\mathrm{it}}=1$, also helps us identify treatment. $D_{t}$ represents our treatment variable. Mother $i$ belongs to the treatment group if the child is born on 1 January 2001 or thereafter, as she then falls under the new parental leave policy, and is assigned to the control group if the year of birth is before 2001; she then benefits from the old, more generous family policy and there is no treatment. The observed outcome is specified as follows:

$$
D_{t}\left\{\begin{array}{l}
=1 \text { if } \mathrm{t} \geq 2001 \mid x_{i t}=1 \\
=0 \text { if } \mathrm{t}<2001
\end{array}\right.
$$

We therefore have a sharp RD setting as the treatment status is deterministic (Angrist and Pischke, 2008; Lee and Lemieux, 2010). ${ }^{12}$ The outcome difference is affected only by the treatment. We focus on the average treatment effect at the cut-off, or jump at $x_{i t}$, at the start of 2001 (Imbens and Lemieux, 2008). We estimate the size of the discontinuity by running the logistic regression specification:

$$
Y_{i t}=\alpha+\beta_{1} x_{i t}+\beta_{2} D_{t}+\beta_{3} x_{i t} D_{t}+\beta_{4 t}+Z_{i t}^{\prime} \gamma+\mu_{i}
$$

Where $Y_{i t}$ is the dichotomous outcome of the treatment for individual mother $i$ at time $t$, and takes the value 1 when the mother becomes self-employed at time $t . x_{i t}$ is the assignment variable, which captures the year in which an individual woman gives birth. $\beta_{2}$ is the main coefficient of interest, which estimates the effect of the treatment $D_{t} . x_{i t} D_{t}$ is the interaction term between the assignment variable and the treatment effect. As both the outcome $Y_{i t}$ and our treatment effect $D_{t}$ are conditional on childbirth $x_{i t}$, this interaction term accounts for a possible false discontinuity by measuring the effect of our treatment $D_{t}$ while controlling for $x_{i t .}$ Therefore the coefficient $\beta_{3}$ should not be significantly different from zero (Lesik, 2006;

\footnotetext{
12 Several assumptions or properties are central for the regression discontinuity to be reliable (Berk and Rauma, 1983; Cappelleri and Trochim, 2015): The cut-off criterion has no room for manipulation, as in our case, children are either born before 1 January, 00.00hrs, or after. The specification for the pre- and post- distribution must be correct; this is inferred by the insignificance of the interaction term. The pre-post treatment estimation for the comparison group must be feasible, that is, there are sufficient pre-test values in the comparison group. Both the treatment and control groups must come from a single pre-test distribution, in this case from the German household panel. The treatment must be uniformly distributed among all participants - all mothers who give birth in Germany are entitled to the same parental leave policy. All assumptions above can be validated in this analysis.
} 
Cappelleri and Trochim, 2015). ${ }^{13} t$ is a time trend dummy which captures the annual change in the probability of becoming a mompreneur, holding constant the effects of the other variables. Finally, $Z^{\prime}{ }_{i t} \gamma$ is a set of control variables, including the total number of children a mother has, the woman's age when she becomes a mother, level of education, and household income. We also add the yearly average percentage of female entrepreneurs in Germany to control for the general trend in entrepreneurship. $\mu$ captures any unobserved factors that affect the mother's choice for self-employment.

Choosing the appropriate bandwidth around the cut-off for the regression discontinuity involves a trade-off between being as close as possible to the cut-off (thereby reducing the number of observations) or enlarging the bandwidth around the cut-off, increasing the number of observations but potentially introducing a bias in the estimate (Lesik, 2006; Van der Klaauw, 2008). We estimate how childbirth and parental leave policies affect mothers' decisions to become self-employed; pregnancy and raising a child or setting up a business take time. Mothers are entitled to 34 months of parental leave and an additional 14 weeks of maternity leave, yielding over three years of time off to make such a decision and to develop their plans. We therefore set the bandwidth around the treatment cut-off to four years before and four years after the new policy takes effect. ${ }^{14,15}$

\section{Results}

\subsection{Validity of comparison between pre-and post-treatment samples}

An RDD assumes that the pre- and post-treatment samples are equivalent in the absence of a treatment effect (Cappelleri and Trochim, 2015). Around the cut-off, mothers should be identical in terms of their observable and non-observable characteristics.

\footnotetext{
${ }^{13}$ For further explanation, see Berk and Rauma (1983) p.23: "In order to produce unbiased estimates of the treatment effect, the two withingroup conditional expectation functions must be linear in the assignment variable and parallel."

${ }^{14}$ Decreasing the bandwidth to three years does not significantly alter the results.

${ }^{15}$ Krishnan et al. (2014) also demonstrate the relevance of using several years around the threshold in estimating the effect of a policy change in a regression discontinuity setting.
} 
Table 2 shows the results of t-tests for equality of means for a diverse set of characteristics such as age, education, marital status, income, work hours, childcare hours, and other characteristics of mompreneurs. Since none of these characteristics are significantly different between both samples, treated and untreated mothers can be considered equivalent in terms of their observable and non-observable characteristics around the cut-off (Imbens and Lemieux, 2008). ${ }^{16}$

Table 2

Comparison of mothers around the cutoff

\begin{tabular}{|c|c|c|c|c|c|c|c|}
\hline & \multicolumn{3}{|c|}{2000} & \multicolumn{3}{|c|}{2001} & \multirow{2}{*}{$\begin{array}{l}\text { Two- } \\
\text { tailed } \mathrm{t} \\
\text { test* }\end{array}$} \\
\hline & Mean & SD & $\mathrm{n}$ & Mean & SD & $\mathrm{n}$ & \\
\hline Age mother (years) & 27.60 & 4.83 & 870 & 27.46 & 4.73 & 783 & 0.55 \\
\hline Years of education & 12.49 & 2.55 & 870 & 12.56 & 2.69 & 783 & -0.59 \\
\hline $\begin{array}{l}\text { Marital status ( } \% \\
\text { married) }\end{array}$ & 55.78 & .4967 & 870 & 54.36 & .4982 & 783 & 0.56 \\
\hline $\begin{array}{l}\text { Net monthly personal } \\
\text { income }(€)\end{array}$ & 1111.78 & 799.32 & 870 & 1116.70 & 815.48 & 783 & 0.90 \\
\hline $\begin{array}{l}\text { Net monthly household } \\
\text { income }(€)\end{array}$ & 3391.11 & 1903.20 & 870 & 3385.95 & 1784.15 & 783 & 0.95 \\
\hline Weekly hours of work & 27.68 & 12.94 & 866 & 27.89 & 13.47 & 777 & 0.75 \\
\hline Daily hours of childcare & 4.52 & 4.42 & 811 & 4.78 & 4.89 & 724 & 0.31 \\
\hline $\begin{array}{l}\text { Age of the youngest child } \\
\text { when mother becomes } \\
\text { mompreneur }\end{array}$ & 2.58 & 1.69 & 27 & 2.48 & 1.84 & 20 & 0.85 \\
\hline $\begin{array}{l}\text { Age of mother when she } \\
\text { becomes mompreneur }\end{array}$ & 34.49 & 5.29 & 27 & 33.19 & 5.49 & 20 & 0.42 \\
\hline $\begin{array}{l}\text { Education years of } \\
\text { mompreneur }\end{array}$ & 13.66 & 2.47 & 27 & 13.50 & 2.40 & 20 & 0.82 \\
\hline
\end{tabular}

Notes.- Table 2 reports summary statistics for several person related characteristics of mothers that gave birth around the cut-off. *Mean(2000)-mean(2001), the p-values of the two tailed t-tests for differences in means show that mothers that gave birth in the year 2000 do not statistically differ from mothers that gave birth in the year 2001 and thus validate that pre- and post-treatment samples are equivalent in the absence of a treatment effect. Significance levels: $* \mathrm{p}<0.10, * * \mathrm{p}<0.05, * * * \mathrm{p}<0.01$.

${ }^{16}$ We compare the observations for mothers who give birth in 2000 and in 2001 . Extending the window around the cut-off to $1999-2002$ or even 1998-2003, yields a statistically significant difference only for marital status. This is, however, not surprising, as being several years apart can induce small statistical differences due to societal evolution. The essence here is that around the cut-off, the years 2000 and 2001 , mothers do not differ significantly. 


\subsection{Main findings}

Figure 3 shows the negative jump at the cut-off year, 2001. Using a logit transformation for our dichotomous outcome variable, we plot the predicted probabilities of becoming a mompreneur against the assignment variable, the year of child birth (Lesik, 2006). The dots represent the mean probability of becoming a mompreneur at each childbirth year. The solid lines show the associated $95 \%$ confidence intervals.

\section{Figure 3}

\section{Regression discontinuity graph}

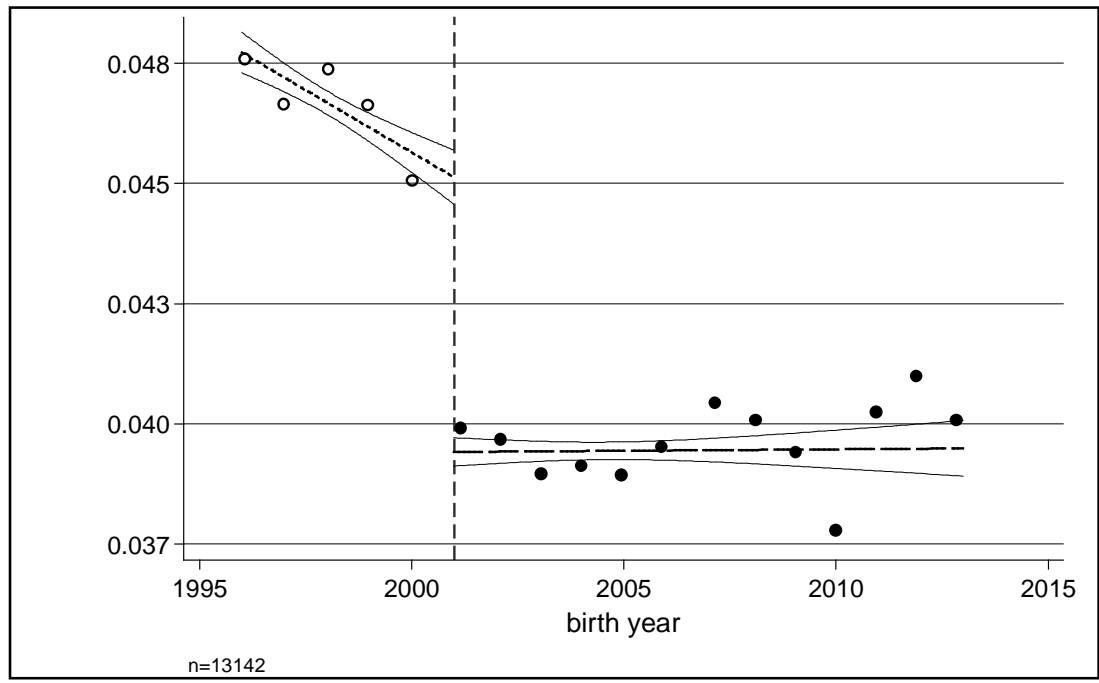

Notes.- Plot of the predicted probability of becoming a mompreneur against the assignment variable, the year of childbirth. The dots represent the mean probability of becoming a mompreneur in each childbirth year. The solid lines show the associated $95 \%$ confidence intervals.

Table 3 shows the estimation results of the logistic regression of equation (1). Both the specification without controls (model 1) and the specification including the various control variables (model 2) show a negative and significant assignment variable (childbirth itself negatively affects the probability of becoming self-employed), and a negative treatment effect that is significant at the 5\% level. After the reduction in parental leave generosity, the propensity for mothers to become self-employed decreased. The logit coefficient of -0.1851 
in model 2 translates into a decrease in the odds of becoming self-employed under the new parental leave policy by nearly $17 \% .^{17}$

\section{Table 3}

Logistic regression analysis for parental leave reform in the year 2001

\begin{tabular}{lcc}
\hline & \multicolumn{2}{c}{ Becoming mompreneur } \\
\hline & Model 1 & Model 2 \\
\cline { 2 - 3 } Child birth $\left(\mathrm{x}_{\mathrm{it}}\right)$ & $-1.4602^{* *}$ & $-1.3167^{*}$ \\
& 0.041 & 0.069 \\
Treatment $\left(\mathrm{D}_{\mathrm{t}}\right)$ & $-0.1801^{* *}$ & $-0.1851^{* *}$ \\
& 0.041 & 0.047 \\
Child birth*treatment $\left(\mathrm{x}_{\mathrm{it}} \mathrm{D}_{\mathrm{t}}\right)$ & 1.0641 & 0.7560 \\
& 0.157 & 0.319 \\
Time trend $(\mathrm{t})$ & $0.0465^{* * *}$ & -0.0013 \\
& 0.000 & 0.924 \\
Female self-employment rate & & $0.6006^{* * *}$ \\
& & 0.000 \\
Number of children & & $0.4430^{* * *}$ \\
& & 0.000 \\
Age mother & & -0.0029 \\
Years of education & & 0.785 \\
& & $0.1503^{* * *}$ \\
Household net income $(\mathrm{ln})^{18}$ & & 0.000 \\
Marital status $(1=$ married) & & -0.0184 \\
Intercept & & 0.858 \\
Pseudo $\mathrm{R}^{2}$ & & $0.4302^{* * *}$ \\
& & 0.000 \\
Person/year observations & & $-10.753^{* * *}$ \\
& & 0.000 \\
& & 0.0553 \\
& & 13,142 \\
\hline
\end{tabular}

Notes.- The table reports the results for the estimation of equation (1) using "becoming a mompreneur" as outcome variable. Model 1 shows the results without control variables and model 2 includes all control variables. P-values are in italics, significance levels: $* \mathrm{p}<0.10, * * \mathrm{p}<0.05, * * * \mathrm{p}<0.01$

\footnotetext{
17 For a detailed overview on the interpretation of logit coefficients and the transformation into odds ratios, see Long and Freese (2006).Alternatively, this coefficient can be interpreted as a decrease in the probability of becoming self-employed of $0.62 \%$-point. Relative to the baseline female self-employment rate of $7.3 \%$ in the year 2000 (the year before the parental leave change), this is an economic decrease of $8.5 \%$.

${ }^{18}$ We control for the monthly household net income as the monthly child rearing benefit payments are income dependent.
} 
To demonstrate that other potential reasons for mothers becoming self-employed do not affect the treatment, we include several control variables (Berk and Rauma, 1983; Lesik, 2006). The positive coefficients for education and being married are in line with existing literature (Carr, 1996; Boden, 1999; Gottlieb et al., 2016), as is the number of children present in the household (Joona, 2018). We also see that the overall rate of female selfemployment matters. Crucially, none of these factors alters our significant treatment estimate.

The interaction term between the assignment variable and the treatment indicator is added to control for a possible false discontinuity. In both regressions, this term is insignificant, confirming that we indeed follow a linear functional form specification in the assignment variable childbirth.

\subsection{Robustness and placebo analysis}

We conduct several analyses to assess whether our results pick up other events rather than the hypothesized change in parental leave policy. ${ }^{19}$ First, we run placebo tests on the year of the policy change. We find that replacing the policy year by, respectively, the years 1999, 2000, 2002, and 2003 and moving the bandwidth around the cut-off accordingly, yields no significant results. In each of these specifications, either the assignment variable "child birth" or the treatment effect turn out to be insignificant. ${ }^{20}$

Next, we test whether the effect we find on mompreneurs could also be found for men. To test for this, we run our model against the dependent variable "dadpreneurs." That is, we use the complete sample of fathers, instead of mothers, that is, men who became fathers between 1996 and 2005. The results are shown in Table 4, models (1) and (2). The assignment variable child birth in these logistic regressions is insignificant, as expected, whereas the treatment coefficient is highly significant. As both the assignment and treatment

\footnotetext{
19 To our knowledge, after consultation of the Bundesgesetzblatt (www.bgbl.de), no other relevant policy change was introduced in Germany at the same time on January 1,2001. We discuss such issues as timing of births and anticipation in the next section.

${ }^{20}$ The results of the placebo tests are shown in Table A. 2 of the appendix.
} 
variables need to be significant for this type of RDD to be reliable, these results show that there is no evidence for an effect from the change in parental leave policy on fathers' decisions to become self-employed. Our dadpreneur results from Table 4 demonstrate that our main results concerning mompreneurs are indeed a female-specific effect of the policy change, that is, a decreased propensity for entrepreneurship by mothers.

\section{Table 4}

\section{Logistic regression analysis for robustness}

\begin{tabular}{|c|c|c|}
\hline & \multicolumn{2}{|c|}{ Becoming dadpreneur } \\
\hline & Model 1 & Model 2 \\
\hline \multirow[t]{2}{*}{ Child birth $\left(x_{i t}\right)$} & -0.1280 & -0.1339 \\
\hline & 0.576 & 0.562 \\
\hline \multirow[t]{2}{*}{ Treatment $\left(D_{t}\right)$} & $-0.5195 * * *$ & $-0.4358 * * *$ \\
\hline & 0.000 & 0.000 \\
\hline \multirow[t]{2}{*}{ Child birth*treatment $\left(\mathrm{x}_{\mathrm{it}} \mathrm{D}_{\mathrm{t}}\right)$} & -0.0831 & -0.1504 \\
\hline & 0.764 & 0.589 \\
\hline \multirow[t]{2}{*}{ Time trend $(\mathrm{t})$} & $0.0390 * * *$ & -0.0177 \\
\hline & 0.000 & 0.299 \\
\hline \multirow[t]{2}{*}{ Male self-employment rate } & & $0.4034 * * *$ \\
\hline & & 0.002 \\
\hline \multirow[t]{2}{*}{ Number of children } & & $0.2241 * * *$ \\
\hline & & 0.000 \\
\hline \multirow[t]{2}{*}{ Age father } & & $-0.0562 * * *$ \\
\hline & & 0.000 \\
\hline \multirow[t]{2}{*}{ Education years } & & $0.1119 * * *$ \\
\hline & & 0.000 \\
\hline \multirow[t]{2}{*}{ Household net income (ln) } & & -0.0377 \\
\hline & & 0.643 \\
\hline \multirow[t]{2}{*}{ Marital status ( $1=$ married $)$} & & $0.3042 * * *$ \\
\hline & & 0.000 \\
\hline \multirow[t]{2}{*}{ Intercept } & $-3.054 * * *$ & $-8.065^{* * *}$ \\
\hline & 0.000 & 0.000 \\
\hline Pseudo $\mathrm{R}^{2}$ & 0.0107 & 0.0385 \\
\hline Person/year observations & 20,848 & 20,848 \\
\hline
\end{tabular}

Notes.- The table reports the results for the estimation of equation (1) using "becoming a dadpreneur" as outcome variable. Model 1 shows the results without control variables and model 2 includes all control variables. P-values are in italics, significance levels: $* \mathrm{p}<0.10, * * \mathrm{p}<0.05, * * * \mathrm{p}<0.01$. 


\section{4 “Donut” RD}

Another important consideration in our regression discontinuity setting is whether mothers can manipulate themselves into or out of treatment by timing the birth of their child, thereby biasing the estimate of the treatment effect. ${ }^{21}$ Neugart and Ohlsson (2013) and Tamm (2013) investigate whether there is evidence of timing of births following the parental benefit reform of 2007, which we detail in the next subsection. These authors find strong evidence that a significant share of employed women timed their births. To our knowledge, there is no similar research regarding the 2001 policy change. We can nevertheless account for potential timing of births by following the "donut RD" approach used by Barreca et al. (2011), that is, removing those births that are close enough to the cut-off to be manipulated.

Our initial estimation is based solely on the birth year of the children. From the Biobirth data set, we can complement this information with the month of birth for most, although not all, mothers. ${ }^{22}$ This slightly reduces the observed number of births to 7,001. We first graph the births over time to check for any visual peaks or troughs (see Figure A.1 in the appendix), detecting no suspicious birth activity around the threshold. Following Barreca et al. (2011), we exclude births in the immediate vicinity of the cut-off, which in our case amounts to all births in December 2000 and in January 2001. We then re-estimate the regression discontinuity on the remaining observations. The results are shown in Table 5 . The coefficient for the treatment effect increases both in magnitude and in significance, and translates into a decrease in the odds of becoming a mompreneur by $21.5 \%$. These findings show that, if anything, our main results may actually underestimate the effect of the policy reform on mothers' propensity to move into self-employment.

\footnotetext{
${ }^{21}$ Another relevant question is whether mothers could anticipate the law change and plan the child's conception accordingly. Reviewing the German media, the earliest account we found about this policy reform was in March 2000. This would thus make such anticipation highly unlikely given that women faced with this less generous policy change would rather be pregnant earlier, not later.

${ }^{22}$ Unfortunately, the Biobirth data set does not provide information concerning day of birth. Neither does it provide the month of childbirth for all children.
} 


\section{Table 5}

\section{Donut RD logistic regression output}

\begin{tabular}{lcc}
\hline & \multicolumn{2}{c}{ Becoming mompreneur } \\
\hline & Model 1 & Model 2 \\
\cline { 2 - 3 } Child birth $\left(\mathrm{x}_{\mathrm{it}}\right)$ & $-1.4352^{* *}$ & $-1.2991^{*}$ \\
& 0.045 & 0.073 \\
Treatment $\left(\mathrm{D}_{\mathrm{t}}\right)$ & $-0.2288^{* *}$ & $-0.2437^{* * *}$ \\
& 0.011 & 0.010 \\
Child birth*treatment $\left(\mathrm{x}_{\mathrm{it}} \mathrm{D}_{\mathrm{t}}\right)$ & 1.0304 & 0.7232 \\
& 0.172 & 0.342 \\
Time trend $(\mathrm{t})$ & $0.0506^{* * *}$ & 0.0030 \\
& 0.000 & 0.832 \\
Female self-employment rate & & $0.5806^{* * *}$ \\
& & 0.000 \\
Number of children & & $0.4652^{* * *}$ \\
& & 0.000 \\
Age mother & & 0.0038 \\
Education years & & 0.728 \\
Household net income $(\ln )$ & & $0.1466^{* * *}$ \\
Marital status $(1=$ married $)$ & & 0.000 \\
Intercept & & -0.0359 \\
& & 0.729 \\
Pseudo $\mathrm{R}^{2}$ & & $0.4010^{* * *}$ \\
Nerson/year observations & & 0.000 \\
& & $-10.595^{* * *}$ \\
& & 0.000 \\
& & 0.0564 \\
& & 12,361 \\
\hline
\end{tabular}

Notes.- The table reports the results for the estimation of equation (1) using "becoming a mompreneur" as outcome variable and removing all observations for childbirths that occurred in December 2000 and in January 2001 and may thus be subject to manipulation. Model 1 shows the results without control variables and model 2 includes all control variables. P-values are in italics, significance levels: $* \mathrm{p}<0.10, * * \mathrm{p}<0.05,{ }^{*} * * \mathrm{p}<0.01$.

\subsection{Money or time?}

Several studies in the broader literature on parental leave policies and female labor supply isolate the labor supply effects of changes in job-protected leave duration from the effects of changes in the duration or level of cash benefit payments. For instance, Asai (2015) finds little evidence that Japanese mothers' labor supply changed in response to increased cash benefits provided during parental leave, whereas Lalive et al. (2014) find that increasing the payment duration of cash benefits, while keeping the length of job-protected leave 
constant, significantly increases Austrian mothers' time at home. Further, Joseph et al. (2013) find that the introduction of a benefit payment period for French mothers during parental leave caused more first time mothers to interrupt their careers. Similarly, in this subsection, we investigate whether the propensity to become a mompreneur depends more on changes in the duration (time) of cash benefit payments or the level (money) of these cash benefits.

Table 6

Logistic regression analysis for parental leave reform in the year 2007

\begin{tabular}{|c|c|c|}
\hline & \multicolumn{2}{|c|}{$\begin{array}{l}\text { Becoming mompreneur } \\
2007\end{array}$} \\
\hline & Model 1 & Model 2 \\
\hline Child birth $\left(\mathrm{x}_{\mathrm{it}}\right)$ & $\begin{array}{c}-0.2993 \\
0.428\end{array}$ & $\begin{array}{c}-0.3291 \\
0.396\end{array}$ \\
\hline Treatment $\left(D_{t}\right)$ & $\begin{array}{c}-0.3623 * * * \\
0.000\end{array}$ & $\begin{array}{c}-0.3752^{* * *} \\
0.000\end{array}$ \\
\hline Child birth*treatment $\left(\mathrm{x}_{\mathrm{it}} \mathrm{D}_{\mathrm{t}}\right)$ & $\begin{array}{c}0.3643 \\
0.404\end{array}$ & $\begin{array}{c}0.2617 \\
0.557\end{array}$ \\
\hline Time trend $(\mathrm{t})$ & $\begin{array}{c}0.0295^{*} \\
0.059\end{array}$ & $\begin{array}{c}0.0482 * * \\
0.045\end{array}$ \\
\hline Female self-employment rate & & $\begin{array}{c}0.2499 \\
0.214\end{array}$ \\
\hline Number of children & & $\begin{array}{c}0.2198 * * * \\
0.000\end{array}$ \\
\hline Age father/ mother & & $\begin{array}{c}-0.236^{* *} \\
0.030\end{array}$ \\
\hline Education years & & $\begin{array}{c}0.2004 * * * \\
0.000\end{array}$ \\
\hline Household net income (ln) & & $\begin{array}{c}-0.4892^{* * *} \\
0.000\end{array}$ \\
\hline Marital status ( $1=$ married) & & $\begin{array}{c}0.2478 * * \\
0.011\end{array}$ \\
\hline Intercept & $\begin{array}{c}-3.323 * * * \\
0.000\end{array}$ & $\begin{array}{c}-4.257 * * \\
0.027\end{array}$ \\
\hline Pseudo R2 & 0.0043 & 0.0379 \\
\hline Person/year observations & 14,168 & 14,168 \\
\hline
\end{tabular}

Notes.- The table reports the results for the estimation of equation (1) using "becoming a mompreneur" as outcome variable and modifying the dataset to include the mothers that gave birth around the 2007 instead of the 2001 policy reform. Model 1 shows the results without control variables and model 2 includes all control variables. P-values are in italics, significance levels: * $\mathrm{p}<0.10, * * \mathrm{p}<0.05, * * * \mathrm{p}<0.01$. 
As the 2001 reform was rather sweeping - for the first time since 1970, the level of generosity decreased in terms of both the payment duration of cash benefits and the level of these cash benefits - we turn to the next relevant policy change after 2001 to disentangle these time and money components. The next relevant reform occurred in 2007 and is apparent in Figure $1 .^{23}$ In 2007, the income-dependent child rearing benefit (Erziehungsgeld) was replaced by an earnings-related "parental benefit" (Elterngeld) (Thévenon and Solaz, 2013; OECD, 2017a and 2017b). The total available months of paid parental leave became 14 months, including the 14 weeks of maternity leave and 2 leave months to be used exclusively by the father. The unpaid job-protected period remained at 34 months in addition to the 14 weeks of maternity leave. ${ }^{24}$ With this reform, mothers that earn higher wages are entitled to substantially higher cash benefits during the leave period than under the 2001 reform $^{25}$ (Spiess and Wrohlich, 2008; Kluve and Tamm, 2013; Neugart and Ohlsson, 2013; Bergemann and Riphahn, 2015; Geyer et al., 2015). In essence, the 2001 reform mainly reduced the duration of cash benefit payments (the "weeks of paid leave," as seen in Figure 1), whereas the 2007 reform mainly altered the level of cash benefits. By estimating the effects of the 2007 reform on the propensity to become a mompreneur, and comparing the outcomes against those of our analysis of the 2001 reform, we can elucidate which component—-time or money—matters more.

Models (1) and (2) in Table 6 show our analyses of the 2007 reform. We find results akin to the results for the dadpreneur alternative: even though the coefficient of the treatment effect is significant, the assignment variable is not. In sum, we find no evidence that the 2007 reform had any effect on mothers' propensity for mompreneurship. This would imply that in

\footnotetext{
${ }^{23}$ There was a small reform in 2002 that removed the obligation for mothers to take leave before childbirth. Mothers could from then on decide to continue working during the 6 weeks prior to birth. We consider this too small a policy change to have a measurable impact. According to Gottlieb et al (2016), such small incremental changes do not induce responses by mothers.

24 See Thévenon and Solaz (2013) and OECD (2017b) for all details concerning the payment schedule.

${ }^{25}$ Calculated as $67 \%$ of the average net monthly income received in the 12 months before childbirth; some mothers are now entitled to receive up to $€ 1,800$ per month (the most extreme situation) for a duration of 12 months, compared to the payment of $€ 450$ per month for 12 months under the 2001 law. See Neugart and Ohlsson (2013) for a detailed numerical explanation and examples of the financial consequences of the 2007 policy reform.
} 
terms of the decision to become self-employed, the duration of cash benefit payments component matters more than the level of cash benefits received during the parental leave period.

\section{Conclusions}

We investigate the impact of the German parental leave reform of 2001, which is contractionary in nature, on mothers' propensity to become self-employed. We find that shortening the period of paid parental leave lowers the odds of mothers becoming selfemployed by $17 \%$. An additional analysis that studies a later reform in 2007 suggests that the reduction in the time component of the parental leave policy matters more to mothers than a change in the financial component of the parental leave policy.

Several robustness checks and placebo tests confirm the reliability of our regression discontinuity setting and our findings. In the placebo test, we find no discontinuity for the years 1999, 2000, 2002, and 2003, nor any effect on dadpreneurs. The robustness test also shows that there is no evidence of birth manipulation around the cut-off. A possible drawback in our analysis is the broad time period of five years around the cut-off that is necessary to attain a sufficient number of observations. As annual data may pick up annual fluctuations besides the policy reform, we control for this in the extended regression model by adding a time trend and controlling for the female self-employment rate. However, using such a longer time period does have the advantage of including mompreneurs for whom the business incubation time is longer.

Our results are in line with Gottlieb et al. (2016), who find an increase of 1.8 percentage points in female entrepreneurship following an increase in the length of jobprotected parental leave from 7 to 12 months in Canada. As such, our study is related and unveils a sort of symmetrical mechanism at work: expansionary parental leave policy reforms 
increase self-employment among young mothers, whereas contractionary parental leave policy reforms decrease self-employment among young mothers. Moreover, as we unveil this using data from Germany - which is a conservative type welfare state as opposed to Canada's liberal system in terms of Esping-Andersen's welfare state typology (Esping-Andersen, 1990) - we also unveil that this mechanism works at least across these two different culturalinstitutional contexts.

Further, our main results, which show a behavioral change by mothers' toward selfemployment around childbirth, due to a change in parental leave policy, provide empirical validity to the emerging literature that argues that mompreneurs constitute a new phenomenon. These mompreneurs are described as mothers who choose to move into selfemployment when they need to care for their young children, and in this way attempt to combine professional ambitions with family responsibilities. This view of mompreneurs is underlined by our descriptive analyses, which show that mompreneurs tend to work more from home and spend more time caring for their children than other mothers who gave birth around the same time period.

A caveat of our study is that we demonstrate the relevance of parental leave policies in mothers' decisions to become self-employed for a country with historically generous parental and family policies, and traditional family roles (Ondrich et al., 1996). This cultural setting might influence women's attitudes toward work in general, and calls for some caution in terms of its applicability to countries with inherently different family policies. Having said that, the symmetry of our results with those of Gottlieb et al. (2016) for Canada, do point towards a mechanism that works across different cultural settings. This is good news for with regard to government policy, and indicates that parental leave policies should be added to the array of policy variables that policymakers consider when designing policies aimed at promoting female entrepreneurship. 


\section{References}

Angrist, Joshua D., and Jörn-Steffen Pischke. 2008. Mostly harmless econometrics: An empiricist's companion. Princeton university press.

Asai, Yukiko. 2015. Parental leave reforms and the employment of new mothers: Quasiexperimental evidence from Japan. Labour Economics, 36: 72-83.

Baker, Michael, and Kevin Milligan. 2008. How does job-protected maternity leave affect mothers' employment?. Journal of Labor Economics, 26(4): 655-691.

Barreca, Alan I., Melanie Guldi, Jason M. Lindo, and Glen R. Waddell. 2011. Saving babies? Revisiting the effect of very low birth weight classification. The Quarterly Journal of Economics, 126(4): 2117- 2123.

Bergemann, Annette, and Regina T. Riphahn. 2015. Maternal employment effects of paid parental leave. IZA Discussion Paper No. 9073. Institute for the study of labor (IZA), Bonn.

Berk, Richard A., and David Rauma. 1983. Capitalizing on nonrandom assignment to treatments: A regression- discontinuity evaluation of a crime-control program. Journal of the American Statistical Association, 78(381): 21-27.

Boden, Richard J. 1999. Flexible working hours, family responsibilities, and female selfemployment. American Journal of Economics and Sociology, 58(1): 71-83.

Budig, Michelle J., Joya Misra, and Irene Boeckmann. 2012. The motherhood penalty in cross-national perspective: The importance of work-family policies and cultural attitudes. Social Politics: International Studies in Gender, State \& Society, 19(2): 163-193.

Cascio, Elizabeth U., Steven J. Haider, and Helena Skyt Nielsen. 2015. The effectiveness of policies that promote labor force participation of women with children: A collection of national studies. Labour Economics, 36: 64-71. 
Camp, Jessica K., Eileen Trzcinski, and Stella Resko. 2016. Family and Labor Market Policies in Germany: The Well-Being of Working Women. In Handbook on WellBeing of Working Women. Dordrecht: Springer Netherlands.

Cappelleri, Joseph C., and William M. Trochim. 2015. Regression discontinuity design. International encyclopedia of the social and behavioral sciences, $2^{\text {nd }}$ edition, 20: 152159.

Carr, Deborah. 1996. Two paths to self-employment? Women's and men's self-employment in the United States, 1980. Work and occupations, 23(1): 26-53.

Carter, Sara, and Tom Cannon. 1992. Women as entrepreneurs: A study of female business owners, their motivations, experiences and strategies for success. Academic Press.

Dahl, Gordon B., Katrine V. Løken, Magne Mogstad, and Kari Vea Salvanes. 2016. What is the case for paid maternity leave?. Review of Economics and Statistics, 98(4): 655670.

Duberley, Joanne, and Marylyn Carrigan. 2012. The career identities of 'mumpreneurs': Women's experiences of combining enterprise and motherhood. International small business journal, 31(6): 629-651.

Dustmann, Christian, and Uta Schönberg. 2012. Expansions in maternity leave coverage and children's long-term outcomes. American Economic Journal: Applied Economics, 4(3): $190-224$.

Ekinsmyth, Carol. 2011. Challenging the boundaries of entrepreneurship: The spatialities and practices of UK 'Mumpreneurs'. Geoforum, 42(1): 104-114.

Ekinsmyth, Carol. 2013. Managing the Business of Everyday Life: the roles of space and place in "mumpreneurship". International Journal of Entrepreneurial Behaviour \& Research, 19(5): 525-546.

Esping-Andersen, Gøsta. 1990. Three worlds of welfare capitalism. Princeton: Princeton 
University Press.

European Commission. 2017. Female entrepreneurs

https://ec.europa.eu/growth/smes/promoting-entrepreneurship/we-workfor/women_en

Fairlie, Robert W., and Alicia M. Robb. 2009. Gender differences in business performance: evidence from the Characteristics of Business Owners survey. Small Business Economics, 33(4): 375-395.

Gangl, Markus, and Andrea Ziefle. 2009. Motherhood, labor force behavior, and women's careers: An empirical assessment of the wage penalty for motherhood in Britain, Germany, and the United States. Demography, 46(2): 341-369.

Gangl, Markus, and Andrea Ziefle. 2015. The Making of a Good Woman: Extended Parental Leave Entitlements and Mothers' Work Commitment in Germany. American Journal of Sociology, 121(2): 511-563.

Gathmann, Christina, and Björn Sass. Forthcoming. Taxing Childcare: Effects on Childcare Choices, Family Labor Supply and Children. Journal of Labor Economics. DOI $10.1086 / 696143$

Geyer, Johannes, Peter Haan, and Katharina Wrohlich. 2015. The effects of family policy on maternal labor supply: Combining evidence from a structural model and a quasiexperimental approach. Labour Economics, 36: 84-98.

Goebel, Jan, Markus M. Grabka, Stefan Liebig, Martin Kroh, David Richter, Carsten Schröder, and Jürgen. 2018. The German Socio-Economic Panel (SOEP). Jahrbücher für Nationalökonomie und Statistik.

Gottlieb, Joshua D., Richard R. Townsend, and Ting Xu. 2016. Experimenting with entrepreneurship: the effect of job-protected leave. NBER Working Paper 22446, National Bureau of Economic Research, Cambridge, MA. 
Gottschall, Karin, and Katherine Bird. 2003. Family leave policies and labor market segregation in Germany: reinvention or reform of the male breadwinner model? Review of Policy Research, 20(1): 115-134.

Haisken-DeNew, John P., and Markus H. Hahn. 2010. PanelWhiz: efficient data extraction of complex panel data sets-an example using the German SOEP. Schmollers Jahrbuch, 130(4): 643-654.

Imbens, Guido W., and Thomas Lemieux. 2008. Regression discontinuity designs: A guide to practice. Journal of econometrics, 142(2): 615-635.

Jean, Melissa, and Caroline S. Forbes. 2012. An Exploration of the Motivations and Expectation Gaps of Mompreneurs. Journal of business diversity, 12(2): 112-130.

Jennings, Jennifer E., and Candida G. Brush. 2013. Research on women entrepreneurs: challenges to (and from) the broader entrepreneurship literature? The Academy of Management Annals, 7(1): 663-715.

Jong, Willemijn de. 2013. Women's Entrepreneurship in the EU, Briefing of the European Parliament's Library. http://www.europarl.europa.eu/RegData/bibliotheque/briefing/2013/130517/LDM_B RI(2013) 130517_REV1_EN.pdf

Joona, Pernilla Andersson. 2018. How does motherhood affect self-employment performance? Small Business Economics, 50(1): 29-54.

Joseph, Olivier, Ariane Pailhé, Isabelle Recotillet, and Anne Solaz. 2013. The economic impact of taking short parental leave: Evaluation of a French reform. Labour Economics, 25: 63-75.

Kalb, Guyonne. 2017. Paid Parental Leave and Female Labour Supply: A Review. Economic Record. DOI: 10.1111/1475-4932.12371 
Kirkwood, Jodyanne. 2009. Motivational factors in a push-pull theory of entrepreneurship. Gender in Management: An International Journal, 24(5): 346-364.

Kluve, Jochen, and Sebastian Schmitz. 2017. Back to Work: Parental Benefits and Mothers' Labor Market Outcomes in the Medium Run. ILR Review, 71(1): 143-173.

Kluve, Jochen, and Marcus Tamm. 2013. Parental leave regulations, mothers' labor force attachment and fathers' childcare involvement: evidence from a natural experiment. Journal of Population Economics, 26(3): 983-1005.

Korsgaard, Steffen. 2007. Mompreneurship as a Challenge to the Growth Ideology of Entrepreneurship. Kontur-Tidsskrift for Kulturstudier, (16): 42-46.

Krishnan, Karthik, Debarshi K. Nandy, and Manju Puri. 2014. Does financing spur small business productivity? Evidence from a natural experiment. The Review of Financial Studies, 28(6): 1768-1809.

Lalive, Rafael, Analía Schlosser, Andreas Steinhauer, and Josef Zweimüller. 2014. Parental leave and mothers' careers: The relative importance of job protection and cash benefits. Review of Economic Studies, 81(1): 219-265.

Lee, David S., and Thomas Lemieux. 2010. Regression discontinuity designs in economics. Journal of economic literature, 48(2): 281-355.

Lesik, Sally Andrea. 2006. Applying the regression-discontinuity design to infer causality with non-random assignment. The Review of Higher Education, 30(1): 1-19.

Long, J. Scott, and Jeremy Freese. 2006. Regression models for categorical dependent variables using Stata. Stata press.

Merz, Monika. 2005. Women's Hours of Market Work in Germany: The Role of Parental Leave. In R. Goméz-Salvador et al. (Eds.), Labour Supply and Incentives to Work in Europe, 153. Edward Elgar Publishing. 
Mullerova, Alzbeta. 2017. Family policy and maternal employment in the Czech transition: a natural experiment. Journal of Population Economics, 30(4): 1185-1210.

Nel, Pieter, Alex Maritz, and O. Thongprovati. 2010. Motherhood and Entrepreneurship: The Mumpreneur Phenomenon. The international journal of organizational innovation, 3(1): 6-34.

Neugart, Michael, and Henry Ohlsson. 2013. Economic incentives and the timing of births: evidence from the German parental benefit reform of 2007. Journal of Population Economics, 26(1): 87-108.

Ondrich, Jan, C. Katharina Spiess, and Qing Yang. 1996. Barefoot and in a German kitchen: Federal parental leave and benefit policy and the return to work after childbirth in Germany. Journal of Population Economics, 9(3): 247-266.

Organisation for Economic Cooperation and Developemnt (OECD), Social Policy Division Directorate of Employment, Labour and Social Affairs. 2017a. PF2.5 Trends in parental leave policies since 1970, March 2017. OECD Family database. www.oecd.org/social/family/database.htm

Organisation for Economic Cooperation and Developemnt (OECD), Social Policy Division Directorate of Employment, Labour and Social Affairs. 2017b. PF2.5 Annex: Detail of change in parental leave by country, April 2017. OECD Family database. www.oecd.org/social/family/database.htm

Orser, Barbara J., Allan L. Riding, and Kathryn Manley. 2006. Women Entrepreneurs and Financial Capital. Entrepreneurship theory and practice, 30(5): 643-665.

Ozurumba, Patrina. 2012. Girl Power: How Female Entrepreneurs Can Overcome Barriers to Successful Businesses. Women's Rts. L. Rep., 34: 24. 
Raute, Anna. 2017. Can financial incentives reduce the baby gap? Evidence from a reform in maternity leave benefits. NBER Working Paper 23793, National Bureau of Economic Research, Cambridge, MA.

Richomme-Huet, Katia, and Virginie Vial. 2014. Business lessons from a "Mompreneurs" network. Global Business and Organizational Excellence, 33(4): 18-27.

Richomme-Huet, Katia, Virginie Vial, and Aude d'Andria. 2013. Mumpreneurship: a new concept for an old phenomenon? International Journal of Entrepreneurship and Small Business, 19(2): 251-275.

Riding, Allan L., and Catherine S. Swift. 1990. Women Business Owners and Terms of Credit: some empirical findings of the Canadian experience. Journal of business venturing, 5(5): 327-340.

Du Rietz, Anita, and Magnus Henrekson. 2000. Testing the Female Underperformance Hypothesis. Small Business Economics, 14(1): 1-10.

Rønsen, Marit, and Marianne Sundström. 2002. Family policy and after-birth employment among new mothers-A comparison of Finland, Norway and Sweden. European Journal of Population/Revue europeenne de demographie, 18(2): 121-152.

Schönberg, Uta, and Johannes Ludsteck. 2014. Expansions in maternity leave coverage and mothers' labor market outcomes after childbirth. Journal of Labor Economics, 32(3): 469-505.

Spiess, C. Katharina, and Katharina Wrohlich. 2008. The parental leave benefit reform in Germany: costs and labour market outcomes of moving towards the Nordic model. Population Research and Policy Review, 27(5): 575.

Tamm, Marcus. 2013. The impact of a large parental leave benefit reform on the timing of birth around the day of implementation. Oxford Bulletin of Economics and Statistics, 75(4): 585-601. 
Thévenon, Olivier, and Anne Solaz. 2013. Labour market effects of parental leave policies in OECD countries. OECD Social, Employment and Migration Working Papers, No. 141, OECD Publishing, Paris.

Van der Klaauw, Wilbert. 2008. Regression-discontinuity analysis: a survey of recent developments in economics. Labour, 22(2): 219-245.

Verheul, Ingrid, and Roy Thurik. 2001. Start Up Capital: Does Gender Matter? Small Business Economics, 16(4): 329-345.

Ziefle, Andrea, and Markus Gangl. 2014. Do women respond to changes in family policy? A quasi-experimental study of the duration of mothers' employment interruptions in Germany. European Sociological Review, 30(5): 562-581. 


\section{Appendix}

Table A.1:

Maternity and parental leave entitlements in Germany, 2001 policy reform ${ }^{26}$.

\begin{tabular}{|c|c|c|c|c|}
\hline & \multicolumn{2}{|c|}{ Before 2001} & \multicolumn{2}{|c|}{ After 2001} \\
\hline & Time & $€$ & Time & $€$ \\
\hline & \multicolumn{4}{|c|}{ Maternity leave (Mutterschutz) 14 weeks, paid at full salary provided by employer. } \\
\hline Parental leave & $\begin{array}{l}\text { (Erziehungsurlaub) } \\
22 \text { months }\end{array}$ & $\begin{array}{l}\text { First } 6 \text { months paid } \\
\text { at } € 300 \text {, after } 6 \\
\text { months payment } \\
\text { eligibility dependent } \\
\text { on average salary. }\end{array}$ & $\begin{array}{l}\text { (Elternzeit) } \\
2 \text { options: } \\
10 \text { months } \\
\text { or } \\
22 \text { months }\end{array}$ & $\begin{array}{l}10 \text { months option } \\
\text { with } € 450 / \text { month, or } \\
22 \text { months option } \\
\text { with } € 300 / \text { month. } \\
\text { Payment eligibility } \\
\text { dependent on } \\
\text { average salary. }\end{array}$ \\
\hline $\begin{array}{l}\text { Job protection } \\
\text { leave }\end{array}$ & 34 months & $\begin{array}{l}\text { Remaining } 12 \\
\text { months (34-22) job } \\
\text { protected but unpaid. }\end{array}$ & 34 months & $\begin{array}{l}\text { Remaining months } \\
\text { (34-10 or } 34-22 \text { ) job } \\
\text { protected but unpaid. }\end{array}$ \\
\hline
\end{tabular}

${ }^{26}$ See Thévenon and Solaz (2013), Ziefle and Gangl (2014), Gangl and Ziefle (2015), and OECD (2017b) for details 
Table A.2:

Logistic regression analysis for placebo policy years 1999, 2000, 2002 and 2003

Become mompreneur Become mompreneur Become mompreneur Become mompreneur 1999 2000 2002 2003

\begin{tabular}{|c|c|c|c|c|c|c|c|c|}
\hline & Model 1 & Model 2 & Model 1 & Model 2 & Model 1 & Model 2 & Model 1 & Model 2 \\
\hline \multirow[t]{2}{*}{ Childborn $\left(\mathrm{x}_{\mathrm{it}}\right)$} & 0.4398 & 0.6053 & -0.0647 & 0.0626 & $-2.083 * *$ & $-1.7602^{*}$ & $-1.4729 * *$ & -1.1203 \\
\hline & 0.278 & 0.148 & 0.890 & 0.896 & 0.038 & 0.082 & 0.040 & 0.121 \\
\hline \multirow[t]{2}{*}{ Treatment $\left(D_{t}\right)$} & $0.2999 * * *$ & $0.3287 * * *$ & $-0.2155 * *$ & $0.2968 * * *$ & 0.01192 & 0.0181 & 0.1105 & 0.0865 \\
\hline & 0.001 & 0.001 & 0.019 & 0.002 & 0.892 & 0.838 & 0.191 & 0.306 \\
\hline \multirow[t]{2}{*}{$\begin{array}{l}\text { Childborn* } \\
\text { treatment }\left(\mathrm{x}_{\mathrm{it}} \mathrm{D}_{\mathrm{t}}\right)\end{array}$} & $-0.9676 * *$ & $1.3022 * * *$ & -0.4055 & -0.6499 & $1.8984 *$ & 1.3722 & 1.2077 & 0.6049 \\
\hline & 0.043 & 0.009 & 0.439 & 0.222 & 0.065 & 0.185 & 0.105 & 0.422 \\
\hline \multirow[t]{2}{*}{ Time trend $(\mathrm{t})$} & $0.1013 * * *$ & $0.0936 * * *$ & $0.0989 * * *$ & $0.0719 * * *$ & $0.0243 * * *$ & -0.0196 & 0.0142 & -0.0159 \\
\hline & 0.000 & 0.000 & 0.000 & 0.000 & 0.009 & 0.129 & 0.127 & 0.192 \\
\hline \multirow[t]{2}{*}{$\begin{array}{l}\text { Female self- } \\
\text { employment rate }\end{array}$} & & -0.0776 & & 0.1611 & & $0.7746 * * *$ & & $0.7509 * * *$ \\
\hline & & 0.656 & & 0.262 & & 0.000 & & 0.000 \\
\hline \multirow{2}{*}{$\begin{array}{l}\text { Number of } \\
\text { children }\end{array}$} & & $0.5865 * * *$ & & $0.5599 * * *$ & & $0.3178 * * *$ & & $0.2852 * * *$ \\
\hline & & 0.000 & & 0.000 & & 0.000 & & 0.000 \\
\hline \multirow[t]{2}{*}{ Age mother } & & 0.0022 & & 0.0023 & & -0.0087 & & -0.0094 \\
\hline & & 0.850 & & 0.832 & & 0.412 & & 0.352 \\
\hline \multirow[t]{2}{*}{ Years of education } & & $0.1408 * * *$ & & $0.1553 * * *$ & & $0.1509 * * *$ & & $0.1553 * * *$ \\
\hline & & 0.000 & & 0.000 & & 0.000 & & 0.000 \\
\hline \multirow[t]{2}{*}{$\begin{array}{l}\text { Household net } \\
\text { income }(\ln )\end{array}$} & & 0.05975 & & 0.0920 & & -0.0426 & & $-0.2287 * *$ \\
\hline & & 0.576 & & 0.388 & & 0.685 & & 0.019 \\
\hline \multirow[t]{2}{*}{$\begin{array}{l}\text { Marital status } \\
(1=\text { married })\end{array}$} & & 0.1952 & & 0.0738 & & $0.4958 * * *$ & & $0.3987 * * *$ \\
\hline & & 0.121 & & 0.530 & & 0.000 & & 0.000 \\
\hline \multirow[t]{2}{*}{ Intercept } & $-3.801 * * *$ & $-6.843 * * *$ & $-3.793 * * *$ & $-8.858 * * *$ & $3.4389 * * *$ & $11.6564 * * *$ & $3.4547 * * *$ & $-9.999 * * *$ \\
\hline & 0.000 & 0.000 & 0.000 & 0.000 & 0.000 & 0.000 & 0.000 & 0.000 \\
\hline Pseudo R2 & 0.0212 & 0.0705 & 0.0193 & 0.0702 & 0.0039 & 0.0553 & 0.0028 & 0.0395 \\
\hline $\begin{array}{l}\text { Person/ year } \\
\text { observations }\end{array}$ & 11,214 & 11,214 & 11,575 & 11,575 & 14,786 & 14,786 & 16,871 & 16,871 \\
\hline
\end{tabular}

Notes.- The table reports the results for the estimation of equation (1) using "becoming a mompreneur" as outcome variable and modifying the treatment year to the years 1999, 2000, 2002 and 2003 respectively. Model 1 shows the results without control variables and model 2 includes all control variables. P-values are in italics, significance levels: $* \mathrm{p}<0.10, * * \mathrm{p}<0.05, * * * \mathrm{p}<0.01$ 


\section{Figure A.1:}

Time series of monthly childbirth rates 2 years around the policy change

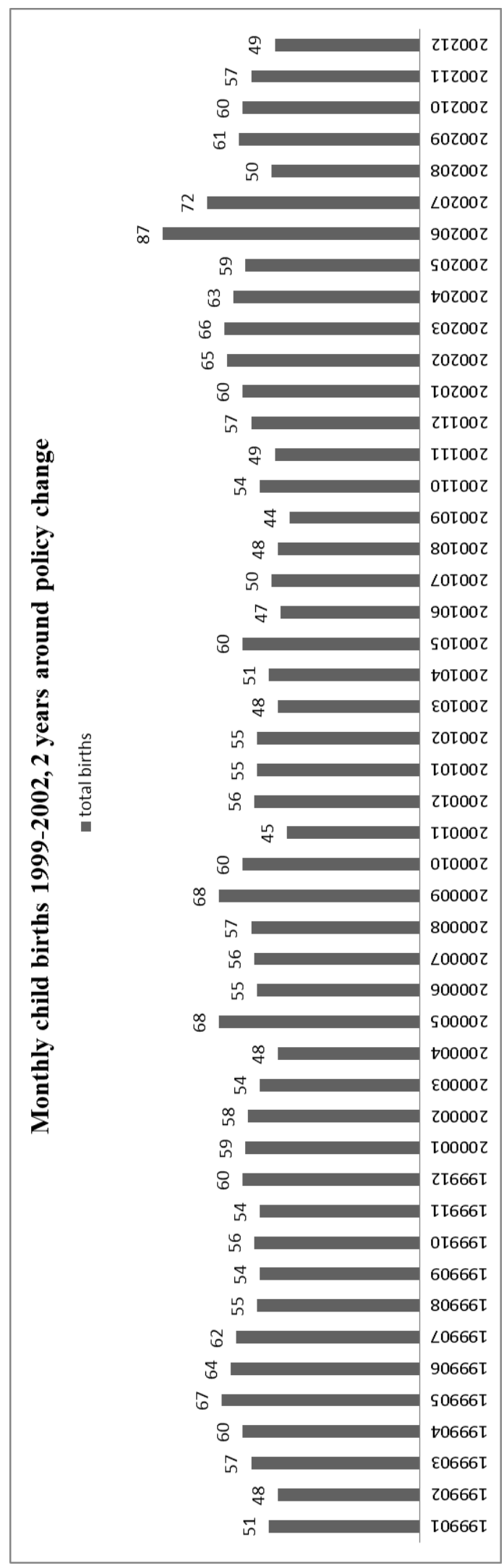

